\title{
THE WORK-LIFE BALANCE OF BLUE-COLLAR WORKERS: THE ROLE OF EMPLOYEE ENGAGEMENT AND BURNOUT
}

\author{
Laila Meiliyandrie Indah Wardani ${ }^{1}$ \& Rahmat Firmansyah \\ Fakultas Psikologi, Universitas Mercu Buana, Jalan Raya Meruya Selatan No. 1, Kembangan, Jakarta Barat, \\ Indonesia, 11650
}

Korespondensi:

le-mail: laila.meiliyandrie@mercubuana.ac.id

\begin{abstract}
The purpose of this study was to determine the effect of employee engagement and burnout on the perception of work-life balance, particularly on bluecollar workers. The study sample comprised of 91 employees of the production section (blue-collar workers) in a multinational company in Jababeka-Cikarang. Sampling was carried out using a stratified technique of proportional approach. The instruments used in this study are The Utrecht Work Engagement Scale (UWES), Maslach Burnout Inventory (MBI-GS), and Work-Life Balance Scale. The study used primary data collection through survey method and secondary data from the company for analysis. Multiple regression analysis showed that employee engagement and burnout influence participants' perceptions on work-life balance. The result indicates that employee engagement and burnout explained 17.6 percent on the variability of participants' perceived work-life balance.
\end{abstract}

Article history:

Received 29 January 2019

Received in revised form 12 June 2019

Accepted 14 June 2019

Available online 18 September 2019

Keywords:

blue-collar workers;

burnout;

employee engagement;

work-life balance

\begin{abstract}
Abstrak - Tujuan penelitian ini adalah mengetahui pengaruh employee engagement dan burnout terhadap work-life balance, terutama pada pekerja blue-collar. Sampel penelitian berjumlah 91 orang karyawan yang bekerja di bagian produksi (blue-collar workers) sebuah perusahaan multinasional di Jababeka-Cikarang. Pengambilan sampel dilakukan dengan menggunakan teknik stratified sampling dan pendekatan proposional. Instrumen yang digunakan untuk pengukuran employee engagement adalah Utrecht Work Engagement Scale (UWES), Maslach Burnout Inventory (MBI-GS), dan Work-Life Balance Scale. Data yang akan digunakan untuk analisis merupakan data primer yang diperoleh melalui metode survei dan data sekunder dari perusahaan. Hasil analisa regresi berganda menunjukkan adanya pengaruh yang positif antara employee engagement dan burnout terhadap work-life balance. Employee engagement dan burnout berkontribusi sebesar 17.6 persen terhadap varians skor persepsi work-life balance partisipan.
\end{abstract}

Kata Kunci: blue-collar workers; burnout; keseimbangan kehidupan kerja; keterlibatan karyawan 


\section{INTRODUCTION}

In the millennial and highly competitive era, technology is invented to assist individuals in various forms of work. Technology also continues to be used to simplify work and to help companies in achieving their production targets. Maximizing the optimal function of technology and employees' potential can be an effective way to deal with unstable economic conditions and to overcome the problems of increasing production costs. Employees in a company have an essential role in company goals achievement. Therefore, human resources are expected to possess necessary competencies to perform the assigned tasks to them. Rapid growth in various sectors create a wider gap in individual's standards of living. In responding to this growth, those who are more literate in using technology would have a better value than those with less technology exposure (Gallup, 2017).

Being a multicultural society with wide geographical scope, Indonesia overcomes particular challenges to control social change and improve economic development (Ratanjee \& Emond, 2013). Badan Pusat Statistik (BPS) reported that Indonesia's economic growth throughout 2018 being at 5.17 percent, which was lower than the targeted set in APBD budget (Laucereno, 2019). BPS also stated that, in August 2018, there were more than 7 million unemployed adults in Indonesia (Kusuma, 2018). Apart from the issue of unemployment in Indonesia, a study found that 85 percent of workers did not have a balance between work and personal life or work-life balance (Fazrina, 2018).

However, the rapid development of millennial generation (Gen Y) and of technology have come to a point where the importance of work-life balance is acknowledged, especially for those living in metropolitan cities. The Dale Carnegie Indonesia survey in 2017 found that millennial workers asserted certain expectations to their workplaces, such as: getting a sense of security from companies, being appreciated by management, being offered competitive prizes, getting a balance between work time and personal life (work-life balance), and having an honest and open-minded supervisors (Anwar, 2017).

Work-life balance is a state where one minimizes conflict between life and work demands. It is essential because work-life balance requires an effective management of work and other aspects of life, such as: family, community activities, voluntary work, self-development, tourism, and recreation (Fazrina, 2018). Therefore, companies need to help employees obtaining a balance between work and personal life in order to produce the best performance and high productivity 
(Delina \& Raya, 2013). An employee is expected to have optimum performance to achieve high level of productivity. Job demands will reasonably reduce the family and social time of the employees. An imbalance between work and family demands can lead to job dissatisfaction (Balmforth \& Gardner, 2006).

Married employees have the responsibilities to take care of their families, and if their work is of high demand, they would need better time management to accommodate family time. On the other hand, for unmarried employees, work-life imbalance arises when high workload takes their leisure time (Makela, Vesa, \& Mayerhofer, 2011). Fisher, Bulger, and Smith (2009) described work-life balance as the competition between time and individual energy used to perform different roles in life. According to a survey by the Society for Industrial and Organizational Psychology in the United States in 2015, 70 percent of employees complained about the duration of working hours as it subsequently decreases their family time (Barsei, 2018). In Indonesia, the results also showed that 85 percent of workers did not have perceive a work-life balance in their life (Fazrina, 2018).

Cowan and Bochantin (2011) found that blue-collar workers often perceive particular challenges in achieving work-life balance due to the nature of the work is often being negative, stressful, and demanding. Work-life balance among blue-collar workers requires different strategies and policies in negotiating work and personal needs. Previous research among blue-collar workers conducted by Frizzell (2015) shows that blue-collar workers do not consider work-life balance when managing their workload.

According to Indonesian Law regarding manpower, the companies are required to implement the maximum working hours of 40 hours per week. However, the regulation may not effectively accommodate the balance between work and personal responsibilities (particularly for married employees) because the regulation does not consider long commuters or after hours inevitable work demands email correspondence (Pulkeria, 2016). Eby, Lockwood, Bordeaux, and Brinley (in Parkes \& Langford, 2008) stated that work-life balance (work-family conflict) is vital for the health and well-being of individuals and family. Study found having a work-life balance could reduce stress and increase life satisfaction (Allen, Herst, Bruck, \& Sutton, in Parkes \& Langford, 2008).

Pandita and Singhal (2017) found work-life balance of employees is related to a sense of employee attachment to the company. Employee attachment is indicated by employees' willingness to give the best work performance, which would result in the organization being more productive (Pandita \& Singhal, 2017). Therefore, companies expect employees engagement to optimally 
perform in all domains, such as productivity, creativity, and innovation (Harter, Schmidt, \& Hayes, 2002). Employee engagement will have a lot of advantages for the company, such as: increasing employee's productivity, increasing efficiency, improving customer satisfaction, reducing turnover, reducing fraud, reducing absenteeism, reducing workplace accidents, and minimizing complaints (in Akbar, 2013).

Schaufeli and Bakker (2004) explained that employee engagement requires positive thinking of employees. It is interpreted as thinking to solve the problem and all things related to work, characterized by vigor, dedication, and absorption. Ratanjee and Emond (2013) found that in 2013, 8 percent of Indonesian employees were engaged at work, while 15 percent were actively disengaged. The actively disengaged employees were those who were not just unhappy and hateful at work due to their need was not being met, they actively expressed their unhappiness. Every day these workers potentially undermine what their engaged co-workers accomplish. If the company does not consider their workplace as a part of economic development and job creation, thus having more disengaged employees, Indonesian economy will run out of professional power in the next few years (Ratanjee \& Emond, 2013).

Gallup's survey (2017) found that only 19 percent of employees in Southeast Asia (Cambodia, Indonesia, Malaysia, Myanmar, Philippines, Singapore, Thailand, and Vietnam) were engaged in their work. The data shows that 81 percent of employees did not engage. The survey also showed that only 22 percent of working-age adults in Southeast Asia who were full-time workers, that number was lower compared to the global data (32\%). A survey in Indonesia of 15,000 workers from 13 companies in 2017 suggested that employee engagement is one of the factors that determine company's ability to facilitate business changes (Syarizka, 2018). The Dale Carnegie Survey in 2017 about employee engagement among millennials found that only 1 in 4 millennia was engaged in their work. However, 64 percent of those who were fully engaged will only survive for another year at work, while 60 percent of millennials planned to resign as soon as they feel disengaged (Anwar, 2017).

The survey conducted in six major cities in Indonesia revealed that three out of four $(75 \%)$ millennial workers did not fully engaged with their company, and 64 percent of them only survived at least for the next year (Carnegie, 2017). Seppala and Moeller (2018) proposed that engagement is the key, for leaders or employees to be motivated, enthusiastic, and productive at work, and to anticipate burnout. Maslach and Leiter (2016) stated that burnout is a psychological syndrome that appears as a prolonged response to chronic interpersonal stress in work. Burnout is characterized by 
extreme fatigue, feelings of cynicism about work, feelings of ineffectiveness, and feeling of underachievement.

The above paragraphs made a case to highlight the importance of employee engagement, burnout, and work-life balance for the sustainability of a company. Therefore, this study was aimed at examining whether and to what extent that employee engagement and burnout influence the perception of work-life balance among blue collar workers in Indonesia. Blue-collar workers taken as the sample group in this present study were those in the production division of a multinational company (PT. AAA).

According to the data from human resources department at PT. AAA, a low level of employee participation in overtime work on Sundays during a quarter period were observed, suggested by only 20-30 percent of employees who were willing to work overtime. Some interviewed employees asserted that they experienced burnout of working from Monday to Saturday, hence they were reluctant to still work on Sunday. Some devoted Sunday for their family. This data provided an initial observation about employees burnout and disengagement, which also alluded a theme of work-life balance, for which PT. AAA provides an appropriate context for this study.

\section{METHOD}

\section{Participants}

Respondents were 91 blue-collar male employees of the production section in a multinational company in Jababeka - Cikarang. The sampling technique used is stratified sampling with a comparative approach of three parts manufacture. Researchers used primary data by distributing questionnaires to a total of 127 respondents who were permanent employees. There were 36 outliers, so total respondents' data that can use in this study were 91 respondents. The research subjects or respondents for this study can be described based on demographic data consisting of age, years of service, position, division of work, education, and marital status. Participants' demographic characteristics are summarized in Table 1. 
Table 1.

Participants Characteristics

\begin{tabular}{|c|c|c|}
\hline Characteristics & $\mathbf{f}$ & $\%$ \\
\hline \multicolumn{3}{|l|}{$\overline{\text { Age }}$} \\
\hline $23-28$ & 47 & 51.6 \\
\hline $29-33$ & 37 & 40.7 \\
\hline $34-40$ & 6 & 6.6 \\
\hline $41-45$ & 1 & 1.1 \\
\hline \multicolumn{3}{|l|}{ Work period (year) } \\
\hline$<5$ & 4 & 4.4 \\
\hline $5-10$ & 78 & 85.7 \\
\hline $10-15$ & 9 & 9.9 \\
\hline \multicolumn{3}{|l|}{ Work division } \\
\hline Process & 25 & 27.5 \\
\hline Production & 66 & 72.5 \\
\hline \multicolumn{3}{|l|}{$\overline{\text { Work sub-division }}$} \\
\hline Operator & 78 & 85.7 \\
\hline Quality Control & 13 & 14.3 \\
\hline \multicolumn{3}{|l|}{ Educational Background } \\
\hline Senior High School & 81 & 89 \\
\hline Diploma & 7 & 7.7 \\
\hline Bachelor & 3 & 3.3 \\
\hline
\end{tabular}

\section{Design}

The study used quantitative research by using survey for data collection. Obtained data were analyzed using multiple hierarchical regression techniques to examine the patterns.

\section{Instruments}

Instruments used in this study was The Utrecht Work Engagement Scale (UWES) by Schaufeli and Bakker (2004) for work engagement, the Maslach Burnout Inventory (MBI-GS) by Maslach and Jackson (1981) for burnout, and the Work-Life Balance Scale by Fisher, Bulger, and Smith (2009) for Work-Life Balance. Data was collected using the Indonesian version of the relevant scales. Adaptation process was undertaken by performing back translation to the scales and having three experts in industrial psychology and psychometric to review the appropriateness of the translation and to anticipate cultural bias given the cultural specificity of the scales. Expert judgment is carried out by a panel of experts, which includes three professors and two doctors who are professional in the field of psychology. So, the three measurements can represent the construct so that the items in the measuring instrument do not change. 
Reliability scores were analysed based on the data of 55 employees conducted as the preliminary study. The Utrecht Work Engagement Scale (UWES) consists of 17 items and has three dimensions ( 6 items of vigor, 5 items of dedication, and 6 items of absorption). Our analysis demonstrated the scale to be reliable, with Cronbach's alpha of .850 .

Maslach Burnout Inventory (MBI-GS) consists of 16 items (10 favorable items) and is divided into three dimensions (5 items of exhaustion, 5 items of cynicism, and 6 items of professional efficacy). Reliability analysis for MBI-GS results in the Cronbach's alpha of .784. Work-Life Balance Scale (WLBS) consists of 17 items representing four areas (5 items for Work Interference with Personal Life [WIPL], 6 items for Personal Life Interference with Work [PLIW], 3 items for Work Enhancement of Personal Life [WEPL], and 3 items for Personal Life Enhancement of Work [PLEW]). Reliability index for WLBS was of .851.

\section{Analysis Technique}

To examine the hypothesis, multiple regression analysis were employed. Multiple regression is a statistical technique to examine linear equations and determine the predictive value of an independent variable towards dependent variables (Kaplan \& Saccuzzo, 2009). This study was to determine the role of work engagement and burnout (as simultaneous independent variables) toward the perception of work-life balance.

\section{RESULTS}

\section{Descriptive Analysis}

The descriptive statistic, hypothetical and empirical values categorization of each variable are summarized in Table 2. 
Table 2.

Hypothetical and Empirical Categorization

\begin{tabular}{|c|c|c|c|c|c|c|c|c|c|c|c|c|c|c|c|}
\hline & \multicolumn{2}{|c|}{ SD } & \multicolumn{2}{|c|}{ Mean } & \multicolumn{2}{|c|}{ X-Min } & \multicolumn{2}{|c|}{ X-Max } & \multirow[t]{2}{*}{ Category } & \multicolumn{2}{|c|}{ Range } & \multicolumn{2}{|r|}{$\mathbf{f}$} & \multicolumn{2}{|r|}{$\%$} \\
\hline & $\mathrm{H}$ & $\mathrm{E}$ & $\mathrm{H}$ & $\mathrm{E}$ & $\mathrm{H}$ & E & $\mathrm{H}$ & $\mathrm{E}$ & & $\mathrm{H}$ & $\mathrm{E}$ & $\mathrm{H}$ & $\mathrm{E}$ & $\mathrm{H}$ & $\mathrm{E}$ \\
\hline \multirow[t]{4}{*}{$\mathbf{E E}$} & 8.5 & 6.59 & 42.5 & 46.73 & 17 & 33 & 68 & 63 & Low & $17-38$ & $33-43$ & 12 & 27 & 13.2 & 29.7 \\
\hline & & & & & & & & & Average & $39-47$ & $44-50$ & 38 & 38 & 41.8 & 41.7 \\
\hline & & & & & & & & & High & $48-68$ & $51-63$ & 41 & 26 & 45 & 28.6 \\
\hline & & & & & & & & & & Total & & 91 & 91 & 100 & 100 \\
\hline \multirow[t]{4}{*}{ BO } & 8 & 4.15 & 40 & 38.48 & 16 & 29 & 64 & 48 & Low & $16-36$ & $29-36$ & 31 & 31 & 34.1 & 34.1 \\
\hline & & & & & & & & & Average & $37-44$ & $37-41$ & 53 & 42 & 58.2 & 46.1 \\
\hline & & & & & & & & & High & $45-64$ & $42-48$ & 7 & 18 & 7.7 & 19.8 \\
\hline & & & & & & & & & & Total & & 91 & 91 & 100 & 100 \\
\hline \multirow[t]{4}{*}{ WLB } & 8.5 & 3.72 & 42.5 & 36.48 & 17 & 27 & 68 & 46 & Low & $17-38$ & $27-35$ & 60 & 36 & 65.9 & 39.6 \\
\hline & & & & & & & & & Average & $39-47$ & $36-38$ & 31 & 24 & 34.1 & 26.4 \\
\hline & & & & & & & & & High & $48-56$ & $39-46$ & 0 & 31 & 0 & 34 \\
\hline & & & & & & & & & & Total & & 91 & 91 & 100 & 100 \\
\hline
\end{tabular}

Remarks: $\mathbf{B O}=$ Burnout; $\mathbf{E E}=$ Employee Engagement; $\mathbf{W L B}=$ Work-Life Balance; $\mathbf{H}=$ Hipotetic; $\mathbf{E}=$ Empiric; $\mathbf{S D}=$ Standard Deviation; $\mathbf{f}=$ frequency

The average score of Employee Engagement in this study was 46.73, being higher when compared to the expectation value of 42.5. This reflects that participants appeared to have quite high engagement to the company. Regarding burnout score, the average value was 38.48 , which is lower than the expected score of 40. This suggests that participants had lower levels of burnout. For work-life balance perception, the average score of participants appeared to be lower than the expected score, which suggests that participants tended to have fewer perception on their balance proportion between work and life.

\section{Basic Assumption Tests}

Prior to conducting regression analysis, basic assumption tests were performed, including: normality test, heteroscedastic test, homogeneity test, linearity test, and multicollinearity test. Data was known to be normally distributed and no heteroscedastic in the relationship between the two variables were observed in this study. Regarding homogeneity, the Levene's value obtained was $1.198(p>0.05)$ and $1.699(p>0.05)$, suggesting homogeneous variance. Multicollinearity was also not detected as the tolerance value was $.980(>.10)$ with VIF index of $1.020(<10.00)$. For linearity test, the result suggests $F$ value of 1.226 ( $p>.05)$, which indicates linearity. 


\section{Hypothesis Testing}

The result showed that employee engagement and burnout significantly determined $(F=$ 9.395; $R=.419 ; p<.01)$ participants' scores of work-life balance. The role of employee engagement and burnout towards work-life balance follows the following equation: WLB $=20.925$ $+0.365 \mathrm{EE}+0.032 \mathrm{BO}$. Employee engagement and burnout accounts for 17.6 percent of the participant's variance of work-life balance.

\section{DISCUSSION}

The result found that there is a significant simultaneous effect of employee engagement and burnout on the perception of work-life balance among blue-collar workers of PT. AAA. Work-life balance is an important topic for employees regardless their work nature because family and career are inseparable aspects of life. Thus, it is important to assist employees in achieving a sense of balance between work and personal needs as an effort to increase productivity and performance.

Results showed that burnout could reduce the perception of work-life balance. Burnout could manifest in the form of intense physical, mental, and emotional fatigue. Psychobiological processes are involved when individual experiences burnout, indicated by psychological stresses manifest in various physical symptoms, such as: loss focus, pain complaints, or being vulnerable to sick. According to Peeters, Montgomery, Bakker, and Schaufeli (2005), pressures from work and family are often inappropriately mitigated, hence increasing the chance towards imbalance management. The imbalance in work or family can substantially impact the overall quality of life.

The study has demonstrated that work-life balance is affected by employee management; this is in concord with previous study (Pandita \& Singhal, 2017). This means high employee engagement would be followed by more balanced management between work and life. Schwartz (2015) explained this pattern by suggesting that employees whose company appreciate and promote their emotional, physical, and social well-being, would feel engage to their work. Moreover, Schwartz (2015) also suggests that a trustful leader and opportunity for balancing work and life aspects would create an ideal atmosphere that determine employees' optimal performance. Robinson (2019) further characterised the opportunity for creating work-life balance by emphasizing flexibility for employees in managing their duties. Such a flexibility would bear dedication and vigor of the employees, which is essential for company's well-being. 
This study indicated a small positive correlation between work-life balance and employee engagement, which is consistent with previous study in this area (Hakanen, Seppala, \& Peeters, 2017; Iqbal et al., 2017; Pandita \& Singhal, 2017; Parkes \& Langford, 2008; Westman, Brough, \& Kalliath, 2009). Employee engagement also implies employees' intention to stay with the company. Mangkunegara and Octorend (2015) stated that employee commitment to the organization could be improved by fousing on the level of job satisfaction. Nurendra and Purnamasari (2017) also found that work engagement is one of the aspects that is influenced by the quality of work-life.

The result of the present study suggests the significant effect of burnout to work-life balance, which means that higher burnout tends to be followed by higher perception of work-life balance. This result is on the contrary of the results from previous studies (Darmawan, Silviandari, \& Susilawati, 2015; Novess, 2015; Pangemanan, Pio, \& Tumbel, 2017).

The significant positive correlation between burnout and work-life balance might be explained by following argument. The questionnaires were distributed during the period when the company offered obligatory consecutive bonuses of Eid Al-Fitr festive season. This might positively bias work-life perception scores, despite the scores of burnout being high. In particular, the work-life balance scale has a dimension of Work Enhancement of Personal Life (WEPL), which refers to the extent to which work can improve the quality of an individual's personal life. Bonuses are one of the factors that can improve the quality of employees' personal life. Being a multinational company, the company offers higher rates compensation than that is ruled by the government, including for blue-collar workers. This could further reduce the effect of burnout. The next factor is the health benefits offered by the company to employees. Employees get double coverarges from the company and National Health Insurance (BPJS) for health benefits (wife and children), thus increase a sense of safety and comfort for employees while working.

Bonuses and benefits that are above the average could provide a sense of achievement of the employees. Greenberg (2011) explained there are external factors that affect burnout, one of which is rewards. Thus, even though employees experienced burnout, it did not present as a major determinant of employees' work-life balance perception.

Second argument might be related to the nature of the variables. According to Kanwar, Singh, and Kodwani (2009), work-life balance is a situational variable, while burnout relates to individual's personality. Work-life balance negatively affects burnout and if the organisation does considerable effort to minimise stress, burnout could be reduced. On the other hand, the 
organisation could take initiation in promoting work-life balance practices to help employees familiarise the issues and manage their concerns effectively (Kanwar, Singh, \& Kodwani, 2009).

The result of this study also revealed that there was no correlation between burnout and work engagement. While this result is supported by the previous finding (Hikmatullah, 2016), the result seems to be in contrary with the growing body of evidence, which suggests a negative correlation between burnout and work engagement (Balasubramanian \& Lathabhavan, 2017; Christianty \& Widhianingtanti, 2016; Fragoso et al., 2016; Hakanen, Bakker, \& Schaufeli, 2006; Hakanen, Seppala, \& Peeters, 2017; Maricutoiu, Sulea, \& Lancu, 2017; Schaufeli, Bakker, \& Van Rhenen, 2009; Sonnentag, 2017; Van Steenbergen, Van Der Ven, Peeters, \& Waris, 2017). Sonnetag (2017) argued the distinction between work engagement and burnout might explain the emerging result. Burnout is a chronic state that results from accumulated experiences of overload, while work engagement is short-lived and is experienced from a situation where task contributes to the experience of meaningfulness and where sufficient resources are present (Sonnetag, 2017). Van Steenbergen, Van Der Ven, Peeters, and Waris (2017) revealed that burnout and work engagement remain stable over time, and the effects of the transition does not depend on employees' psychological capital.

\section{Limitation}

The study acknowledges several limitations. The study sample was from a company, for which limits the generalizability power of the results. Participants were also from a particular division (Production Division) and were all male. The study timing, which was conducted during the important Festive Season, might produce bias towards the results. Another limitation is the analysis could not confidently justify the findings that burnout positively correlated with the perception of work-life balance given the small sample size and uncontrolled extraneous variables that might intervene the results.

\section{REFERENCES}

Akbar, M. R. (2013). Pengaruh budaya organisasi terhadap employee engagement (Studi pada karyawan PT. Primatexco Indonesia di Batang). Journal of Social and Industrial Psychology, 2(1), 10-18. 
Anwar, F. (2017). Engagement tenaga kerja milenial Indonesia hanya 25\%. Retrieved from https://youngster.id/featured/engagement-tenaga-kerja-milenial-indonesia-hanya-25

Balasubramanian, S. A., \& Lathabhavan, R. (2017). Women's glass ceiling beliefs predict work engagement and burnout. Journal of Management Development, 36(9), 1125-1136. doi: 10.1108/jmd-12-2016-0282

Balmforth, K., \& Gardner, D. (2006). Conflict and facilitation between work and family: Realizing the outcomes for organizations. New Zealand Journal Psychology, 35(2), 69-76.

Barsei, A. N. (2018). Fenomena "work balance”. Retrieved from https://www.kompasiana.com/tyobarsei/5ab46266caf7db4c3a37b063/fenomena-work-lifebalance

Carnegie, D. (2017). Mayoritas milenial galau dalam pekerjaan, kamu juga? Retrieved from https://www.dalecarnegie.id/sumberdaya/media/media-coverage/mayoritas-milenial-galaudalam-pekerjaan-kamu-juga/

Christianty, T. O. V., \& Widhianingtanti, L. T. (2016). Burnout ditinjau dari employee engagement pada karyawan. Psikodimensia, 15(2), 351-373.

Cowan, R. L., \& Bochantin, J. E. (2011). Blue-collar employees' work/life metaphors: Tough similarities, imbalance, separation, and opposite. Qualitative Research Reports in Communication, 12(1), 19-26. doi: 10.1080/17459435.2011.601521

Darmawan, A., Silviandari, I., \& Susilawati, I. (2015). Hubungan burnout dengan work-life balance pada dosen wanita. Jurnal Mediapsi, 1(1), 28-39.

Delina, G., \& Raya, R. P. (2013). A study on work-life balance in working women. International Journal of Commerce, Business, and Management (IJCBM), 2(5), 274-282.

Fazrina, F. N. (2018). Work-life balance: Gimana menyeimbangkan kerja dan kehidupan. Retrieved from http://brilio.net/creator/work-life-balance-menyeimbangkan-kehidupan-kerja-dengankehidupan-072158.html

Fragoso, Z. L., Holcombe, K. J., McCluey, C. L., Fisher, G. G., McGonagle, A. K., \& Friebe, S. J. (2016). Burnout and engagement. Workplace Health \& Safety, 64(10), 479-487. doi: $10.1177 / 2165079916653414$

Fisher, G. G., Bulger C. A., \& Smith C. S. (2009). Beyond work and family: A measure of work/nonwork interference and enhancement. Journal of Occupational Health Psychology, 14(4), 441-456. 
Frizzell, R. E. (2015). Manufacturing satisfaction with work-family balance: The effect of employee, technology use, and life role salience (Unpublished dissertation). Department of Psychological Sciences, College of Arts and Sciences, Kansas State University, Manhattan, Kansas.

Gallup. (2017). State of the global workplace. New York, NY: Gallup Press.

Greenberg, J. (2011). Behavior in organization: Understanding and managing the human side of work (10th ed.). United States, US: Prentice-Hall.

Hakanen, J. J., Bakker, A. B., \& Schaufeli, W. B. (2006). Burnout and work engagement among teachers. Journal of School Psychology, 43(6), 495-513. doi:10.1016/j.jsp.2005.11.001

Hakanen, J. J., Seppala, P., \& Peeters, M. C. W. (2017). High job demands, still engaged, and not burned out? The role of job crafting. International Journal Behavioral Medicine, 24(4), 619-627. doi: 10.1007/s12529-017-9638-3

Harter J. K., Schmidt F. L., \& Hayes T. L. (2002). Business-unit-level relationship between employee satisfaction, employee engagement, and business outcomes: A meta-analysis. Journal of Applied Psychology, 87(2), 268-279.

Hikmatullah, F. (2016). Hubungan employee engagement dan burnout pada karyawan divisi IT. Jurnal Elektronik, 9(1), 100-108.

Iqbal, I., Zia-ud-Din, M., Arif, A., Raza, M., \& Ishtiaq, Z. (2017). Impact of employee engagement on work-life balance with the moderating role of employee cynicism. International Journal of Academic Research in Business and Social Sciences, 7(6), 1088-1101. doi: 10.6007/IJARBSS/v7-i6/3068

Kanwar, Y. P. S., Singh, A. K., \& Kodwani, A. D. (2009). Work-life balance and burnout as predictors of job satisfaction in the IT-ITES industry. Vision: The Journal of Business Perspective, 13(2), 1-12. doi: 10.1177/097226290901300201

Kaplan, R. M., \& Saccuzzo, D. P. (2009). Psychological testing: Principles, application, and issues. United States, US: Wadsworth.

Kusuma, H. (2018). Data BPS: Masih ada 7 juta orang nganggur di Indonesia. Detik. Retrieved from http://finance.detik.com/berita-ekonomi-bisnis/d-4288074/data--bps-masih-ada-7-jutaorang-nganggur-di-indonesia

Laucereno, S. F. (2019). Harga komoditas hingga ekonomi global loyo, ekonomi RI tumbuh 5,17 persen. Detik. Retrieved from http:/finance.detik.com/berita-ekonomi-bisnis/d445720/harga-komoditas-hingga-ekonomi-global-loyo-ekonomi-ri-tumbuh-517 
Mangkunegara, A. P., \& Octorend, T. R. (2015). Effect of work discipline, work motivation, and job satisfaction on employee organizational commitment in the company (Case study in PT. Dada Indonesia). Universal Journal of Management, 3(8), 318-328. doi: 10.13189/ujm.2015.030808

Makela, L., Vesa, S., \& Mayerhofer, H. (2011). Lives of female expatriates: Work-life balance concerns. Gender in Management: An International Journal, 26(4), 256-274.

Maricutoiu, L. P., Sulea, C., \& Lancu, A. (2017). Work engagement or burnout: Which comes first? A meta-analysis of longitudinal evidence. Burnout Research, 5, 35-43. doi: 10.1016/j.burn.2017.05.001

Maslach, C., \& Jackson, S. E. (1981). The measurement of experienced burnout. Journal of Organizational Behaviour, 2(2), 99-113. doi: 10.1002/job.4030020205

Maslach, C., \& Leiter, M. P. (2016). Understanding the burnout experience: Recent research and its implications for psychiatry. World Psychiatry, 15(2), 103-111. doi: 10.1002/wps.20311

Novess, J. (2015). The influence of burnout symptoms on the relationship between work-life balance and self-rated health (Unpublished thesis). Faculty of Applied Health Sciences, Brock University St. Catharines, Canada.

Nurendra, A. M., \& Purnamasari, W. (2017). Hubungan antara kualitas kehidupan kerja dan keterikatan kerja pada pekerja wanita. Indigenous: Jurnal Ilmiah Psikologi, 2(2), 148-154.

Pandita, S., \& Singhal, R. (2017). The influence of employee engagement on the work-life balance of employees in the IT sector. The IUP Journal of Organizational Behavior, 16(1), 38-57.

Pangemanan, F. L., Pio, R. J., \& Tumbel, T. M. (2017). Pengaruh work-life balance dan burnout terhadap kepuasan kerja. Jurnal Administrasi Bisnis, 5(3), 1-8.

Parkes, L. P., \& Langford, P. H. (2008). Work-life balance or work-life alignment? A test of the importance of work-life balance for employee engagement and intention to stay in organization. Journal of Management and Organization, 14(3), 267-284. doi: $10.1017 / \mathrm{S} 1833367200003278$

Peeters, M. C. W., Montogomery, A. J., Bakker, A. B., \& Schaufeli, W. B. (2005). Balancing work and home: How job and home demands are related to burnout. International Journal of Stress Management, 12(1), 43-61. doi: 10.1037/1072-5245.12.1.43

Pulkeria, R. (2016). Work or life? Or work-life balance? Retrieved from http://blog.karir.com/2016/10/05/work-or-life-or-work-life-balance/ 
Ratanjee, V., \& Emond, L. (2013). Why Indonesia must engage younger workers. Retrieved from https://news.gallup.com/businessjournal/166280/why-indonesia-engage-youngerworkers.aspx

Robinson, J. (2019). The scientific link that drives employee engagement and productivity. Retrieved from https://www.worktolive.info/blog/the-scientific-link-between-work-lifebalance-employee-engagement-and-productivity

Schaufeli, W. B., \& Bakker, A. B. (2004). Job demans, job resources, and their relationship with burnout and engagement: A multi-sampe study. Journal of Organizational Behavior, 25, 293-315. doi: 10.1002/job.248

Schaufeli, W. B., Bakker, A. B., \& Van Rhenen, W. (2009). How changes in job demands and resources predict burnout, work engagement, and sickness absenteeism. Journal of Organizational Behavior, 30(7), 893-917. doi: 10.1002/job.595

Schwartz, T. (2015). When employee engagement turns into employee burnout. New York Times. Retrieved from https://www.nytimes.com/2015/03/14/business/dealbook/when-employeeengagement-turns-into-employee-burnout.html

Seppala, E., \& Moeller, J. (2018). 1 in 5 employees is highly engaged and at risk of burnout. Retrieved from https://hbrascend.org/topics/1-in-5-employees-is-highly-engaged-and-atrisk-of-burnout/

Sonnentag, S. (2017). A task-level perspective on work engagement: A new approach that helps to differentiate the concepts of engagement and burnout. Burnout Research, 5, 12-20. doi: 10.1016/j.burn.2017.04.001

Syarizka, D. (2018). Sumber daya manusia: Keterikatan karyawan tentukan kemampuan adaptasi perusahaan. Retrieved from http://sumatra.bisnis.com/read/20180403/448/779079/sumberdaya-manusia-keterikatan-karyawan-tentukan-kemampuan-adaptasi-perusahaan

Van Steenbergen, E. F., Van Der Ven, C., Peeters, M. C., \& Waris, T. W. (2017). Transitioning towards new ways of working: Do job demands, job resources, burnout, and engagement change? Psychological Reports, 121(4), 736-766. doi: 10.1177/0033294117740134

Westman, M., Brough, P., \& Kalliath, T. (2009). Expert commentary on work-life balance and crossover of emotions and experiences: Theoretical and practice advancements. Journal of Organizational Behavior, 30(5), 587-595. doi: 10.1002/job.616 